\title{
The Discussion of the Virtual Simulation Model of the College Students' Entrepreneurship Based on the Maker Spirit
}

\author{
(PRESENTED) \\ ZHANG Yue \\ ChongQing Technology And Business University \\ Chongqing China \\ 28283504@qq.com
}

\begin{abstract}
The upcoming of the entrepreneurial century of Mass Entrepreneurship and Innovation requires the reformation of the college entrepreneurship education. The economic management experimental teaching center of the ChongQing Technology And Business University (CTBU) firstly brings in the concept of Maker to the entrepreneurship virtual simulation (EVS) course in the economic management majors and carries out a bold reform and innovation combining the current available resource in the school. This is a case study about entrepreneurship virtual simulation by CTBU
\end{abstract}

Keywords-Maker spirit; college students; entrepreneurship virtual simulation

\section{INTRODUCTION \&BACKGROUND}

China has entered a new time of "popular entrepreneurship and innovation". "Popular entrepreneurship" means that entrepreneurship has become a popular normal, thus entrepreneurship education has been raised to an important status. Entrepreneurship education in foreign countries can be traced back to 1947, when Prof. Myles Mace of Business School of Harvard University first opened a course called New Entrepreneurship Management which was taken as the first appearance of entrepreneurship education in the United State universities. Until 2010, more than 1700 universities and colleges in the US have opened entrepreneurship education courses. Thus entrepreneurship education course system in US universities and colleges have become relatively sound. In many countries, entrepreneurship education runs through the entire study life of students. Entrepreneurship education in countries generally consists of two parts: theoretical teaching and practical teaching, with the latter is emphasized more. Compared with the mature entrepreneurship education in the Western countries, China's entrepreneurship education started relatively late, starting from Tsinghua University in 2002, experimenting in 9 famous universities and colleges like Beijing University of Aeronautics and Astronautics and having a short history of about 10 years. It stressed theoretical teaching, but mere theoretical teaching cannot satisfy students' requirement for entrepreneurship courses. Currently, there has been a tide of entrepreneurship in Chinese universities and colleges, which is calling for urgent reform of entrepreneurship education. Students are eager to learn more useful entrepreneurship knowledge and skills in class and hope to have more practical courses with stimulation of real entrepreneurship besides theoretical knowledge.

Presently, most the colleges that offer the courses of entrepreneurship virtual simulation are based on the lab environment and achieve through human-computer interaction by adopting the single computer or online software, such as "Entrepreneurship Star" to simulate the process of registering a company. Or in the form of contest, we can complete a segment of entrepreneurship and have the students' abilities trained in the process of contest., like "Business Plan contest" . Nonetheless, all these forms only intercept one step of the whole process and are unable to engage the student in participating the whole process of entrepreneurship. Some colleges only pay attention to theories and focus on the cultivation of their abilities instead of put entrepreneurship into practice. Students said what they have learned was limited. There is disconnect between theory and practice in China's practical entrepreneurship education.

"Popular innovation" means entrepreneurs must have concept of innovation in their entrepreneurship. "Innovation comes before entrepreneurship".In china "chuangke" originates from the English "Maker", which means those people trying to convert ideas into realities out of interests and hobbies. Baidu Encyclopedia's definition of Maker is: people who is stick to innovation, keeps practicing, happy to share and pursues beautiful life. Nevertheless, there is no precise and agreed definition toward Maker. In this paper, maker is preferably defined as individuals or groups who meet the customer needs based on the innovation as their core idea and persistent belief and an incarnation of faith and spirit. Therefore, Maker and Maker Spirit are bound to become the main theme for the future entrepreneurship. Makers are full of originalities, designs, enthusiasm and are willing to bring joyful life for others. Maker can be an individual or a group which satisfies customer needs, thus rendering its originality with commercial values, whereas Makers start from interests and hobbies and its core competitiveness of creativity complying with the innovation trends of contemporary world.

Therefore, it is foreseeable that such innovative spirit of "Makers" will become the theme of entrepreneurship in future. College students are a special group of current entrepreneurial climate, who are educated with the most classical theory and are open-minded to receive the forefront of information. They are 
not restricted to the tradition and they teem with infinite ideas, many of which can be transformed into productivity. At Present, many Maker community is dominated by College students. CTBU creatively introduce Maker concept into the teaching of the EVS of the economic management majors, highlighting that the faith of entrepreneurship is innovation and under the guidance of the Maker spirit, they started the first entrepreneurial practice experimental class, which consist of online and offline. Online means the simulation in the classroom, while offline means the actual simulation in the entrepreneurship base in the CTBU, which in total forms the all-around simulative experimental mode of entrepreneurship. The experimental class recruits from the whole university and those students who are interested in the program and with their own ideas or innovation projects can register for participation. The class accepted 27 students then and the detailed course design is shown in the Figure 1 below. This class is a beneficial exploration of the introduction of Maker Spirit to the College students' EVS.

Fig 1 Course Design of the Entrepreneurship Experimental Class

\begin{tabular}{|c|c|c|c|}
\hline $\begin{array}{l}\text { Time } \\
\text { Allotment }\end{array}$ & $\begin{array}{l}\text { Teaching } \\
\text { Form }\end{array}$ & Course Content & Problems To Be Solved \\
\hline $1-4$ & Interactive & $\begin{array}{l}\text { Dream } \\
\text { elaboration and } \\
\text { form dream team }\end{array}$ & $\begin{array}{l}\text { Inspire the primitive } \\
\text { urge of students to } \\
\text { entrepreneurship and form a } \\
\text { project team }\end{array}$ \\
\hline $5-6$ & $\begin{array}{l}\text { Theoretica } \\
1\end{array}$ & $\begin{array}{l}\text { Entrepreneur } \\
\text { ship } \\
\text { enhancement, } \\
\text { draft of business } \\
\text { plan }\end{array}$ & $\begin{array}{l}\text { Improve the core } \\
\text { competency of Students }\end{array}$ \\
\hline $7-10$ & Interactive & $\begin{array}{c}\text { Entrepreneur } \\
\text { ial } \\
\text { communication } \\
\text { based on the } \\
\text { project }\end{array}$ & Determine the project \\
\hline $11-12$ & $\begin{array}{l}\text { Theoretica } \\
1\end{array}$ & $\begin{array}{l}\text { Introduce } \\
\text { the mainstream } \\
\text { ways of } \\
\text { financing }\end{array}$ & $\begin{array}{l}\text { Determine the capital } \\
\text { source of the project }\end{array}$ \\
\hline
\end{tabular}

This paper focuses on the process of the EVS course conducted by the Economic Management Experimental Center of the CTBU, gives a preliminary discussion of the college students' EVS experimental mode based on the maker spirit and finally brings forward improvement measures and suggestions based on the outcome of this experiment.

\section{FliP THE ClASSROOM AND LEARN EXPERIMENTAL START-UP THROUGH PRACTICE}

In previous teaching, students said that teachers talked about too many entrepreneurship theories in class with few practice. In this teaching design, we use a teaching model of flipped class to try to solve this problem. Flipped class is a brand-new teaching model which was first put forward by two chemical teachers in a US high school and prelimimary school, Jonathan Bergmann and Aaron Sams, in 2011. In this teaching model, students learn theoretical knowledge after class, class time is used for interactions between teachers and students or among students, and teachers are only a host and guide of class. Through flipping of class majority, students' initiative and positivity are mobilized to the maxim and the teaching effect becomes better.

Based on this theory, the students are absolute the main part of this EVS class. The total time allotment of this class is 12class-hour and the theory part takes one third of the total hour and the two thirds of the time are used for the students to talk about their ideas and plans, where necessary theory support should be available: draft of the entrepreneurship and present main financing approach. As regard to the financing, the internet financing methods and routes are highlighted. What we do is as follows.

\section{A. Build Up An Entrepreneurial Dream Team}

\section{1). White Paper Depicting Entrepreneurial Dreams}

At beginning of this course, each student is given a A4 size white paper, a blue pen and a red pen. Teacher asked in ten minute they shall draw their own start-up dream and these dreams are about the images that form in their respective minds which should original.

After this time, Some students draw a cabin and within is his own coffee house, while some draw a cartoon, some draw parents taking their children, etc. All are simple and sweet pictures. In this way, the students are brought into visions of entrepreneurship.

\section{2). Explain the Dream to Partners}

Then every students get on stage to explain their dreams to other students and the teachers for 5-8 minutes. Through this presentation the students tell their own ideas and blueprints out loud and their original ideas toward their own projects,

In this step is to inspire students' motivation and activate classroom atmosphere. The students are told to brainstorm through this face-to-face contact and communication. Some of them even have a new idea.

\section{3). Free to Form Dream Team}

We learn that successful entrepreneurship is not always achieved by a single person instead of the result of like-minded group and team under the pool of wisdom and efforts of everyone. During the third step, we start the activity of seeking partners . After the previous step, many students have found out others' dreams and ideas and they can find people with similar ideas to form a dream team. The dream team consists three people in a group and they are required to determine a specific project in the class. The three people shall divide their own work in the first place and begin to carry out their project further.

From the previous step, we know that many students' dream are operable, while some students share similar ideas and theirs overlap with others, such as there are three girls talking about opening a theme-coffee house and their difference only lies in variant focus. So this three girls are form a group .At the end all the students are form 9 groups to start the task of next stage.

\section{B. Design A Blueprint of Entrepreneurship Through Projects Orientation}

Colleges' entrepreneurship education is now in seeking its ways in many universities in China. The courses for entrepreneurship are basically theories. The environment for entrepreneurship has never been so open as today's. The government has released related polices to aid entrepreneurship. College students facing serious employment environment therefore many of them are eager to start their own business. Most of the college students are expecting to learn some knowledge about establishing a business in classroom and get their entrepreneurial ability enhanced. Data shows that $37.73 \%$ of the college students believed that they lack effective instruction on starting a business. The fact is that the failure rate of college students' business is above $90 \%$.

A business requires a market. A project which is workable and practical is key to avoiding failures in a new-established business. The key point of "maker" is to satisfy other's demands. Based on that, in our teaching design, projects are always the main theme. The whole course is project-oriented.

1) Focus on the Theme of The Newly Established Business.

Every team sets its theme of their business after they meet their team members. Considering the characteristics of students in schools of business and economics, we emphasize that what 
matters about the goal is not its size but its possibilities of being achieved. We also reiterate that their goal should has a market, even though it's merely a school market.

Nine groups of students define nine themes, such as themed cafe, travel agency aiming at undergraduate students, campus app, etc. Team members divide their works according to their majors and get prepared for the implementation of their projects.

\section{2) Fill in Business Plan, Clear Up Your Minds}

After the theme is decided, every team needs to fill in the Application of Business Plan. It will take students after class time to finish. The plan is strictly designed according to the format. The plan includes the following points: 1 . the purpose and significance of the project. 2. the studying objects and the key problems to be solved 3 . the basic requirement for the studying and implementing of the project. 4. the implementing plan. 5. the conditions that school can provide. 6. expected achievements. The Application of Business Plan is the Business Proposal for projects in real society. Writing the Proposal has dual purposes: it lays bases for applying the Angle Fund and the further venture capital and it works as a connection between start-up teams and investors.

During filling this plan students found some problems. They solve these problems through communication with teachers and teammates or other makers. Through answering the above questions, students can clear their head further, correct their ideas, analyze the pros and cons of the project, also the project's chances and challenges, market and the way of implementation. They can also improve their ideas and polish their previous thoughts. This proposal is also discussed by peers through brainstorming in class, so that every thought of every team can have a chance to get improvements with every one's ideas and hard work.

\section{3) Design Questionnaire and Survey Market Potential}

Based on the preliminary Application, students begin to design market research questionnaire of their teams' projects and survey relevant 3 to 5 companies the business of which shall correlate to the projects determined by the Dream Team. It will takes students one week after class time to finish. All questionnaire of all the team shall consist two parts, the first part surveys the common problems such as the time of establishment, scale of initial and current stage and its situation of profit and loss and their future development promise; the second part surveys questions related to the projects as per teams' determined projects combing with the industry situations.

After the investigation, students said that through investigation to relative enterprises, they had been more clear about their entrepreneurship goals, foresaw possible problems in the course of entrepreneurship and got themselves psychologically fully prepared for it. The complete of the questionnaire has not only enriched the project vision but also laid a solid foundation for the next-step draft of survey report and for the Dream Team to establish company after they finish the project .

\section{4) Draft Survey Report and Find The Start Point}

After investigation to enterprises by questionnaires, students need to write investigation report.

Through investigation, each team acquired first hand real data and had a deep understanding of their own projects. In the investigation reports, team members made analysis on industries, innovations and anticipated market demands of their projects, found initiating point of project implementation. Based on the market demand and project innovation, the entrepreneurship is initiated with a definite object in view and with the possibility of failure to the minimum.

\section{Integrate Resources to Initialize Entrepreneurship.}

The upcoming of Internet plus has revolutionized the way and implement approach of entrepreneurship and the place for the entrepreneurship has reduced to the size of several office desks or computers or even in a discarded factory and buildings, whereas the development of crowd-sourcing and crowd-funding have provided a benign space and soil for the early-stage entrepreneurs, enabling them to realize their ideas and the public is overwhelmed by endless emergence of new things.

We imitate the current popular ways in the Maker Zone to post students' projects in the school platform and publish requirements of entrepreneurial teams toward the place, fund, resources, applicable technique and marketing, recruit all kinds of competent talents, seek individuals or group who can solve team's problems and integrate all kinds of resources to help the teams to achieve their dreams. After all the necessary conditions are met, the team officially initialize the entrepreneurship as according to their own ideas.

\section{EFFECT AND IMPROVEMENT MEASURES}

\section{A. The Results of the Experimental Class}

\section{1) The Results of The Experimental Class}

The experimental class of this entrepreneurial activity nourished 9 projects, which proved workable and valuable with $100 \%$ satisfaction from students who believe the class beneficial According to our analysis on students answered questionnaires, compared with mere theoretical teaching, they like practical courses much more. Next we are going to select proper projects and take them to the business incubator in Chongqing Technology and Business University (CTBU), bring new breezes to the entrepreneurial base. Some outstanding projects are selected to apply for the Angle Fund to fulfill their social value. In this experimental class, we are the pioneers who first introduce the Maker to the practical teaching of entrepreneurship.

2) Connection with Current Campus Entrepreneurial Companies

Currently there are 22 entrepreneurial bases run by college students in our country. These companies are various in consulting, financial, tourists, service business, etc. 4 of these companies are registered as micro-enterprise. The 22 companies take over 7 projects of the experimental class according to their actual situation. They aided these entrepreneurial teams to fulfill their ideas, and they extend their own company's business at the same time. Up till now, this experimental class has finished the whole process of teaching from class to practice, and from theory to reality.

\section{CONCLUSION}

Through this practical course, we reached conclusions as follows:

- In entrepreneurship, students received more help from practical courses than from theoretical courses.

- In class teaching of entrepreneurship education, the teaching method of flipped class is more effective than traditional teaching methods. This method inspired student's original entrepreneurship

- "Maker" spirit should be spread in university campus and it will encourage students' entrepreneurship better.impulse and positivity, digging more internal drive for their entrepreneurship.

- Entrepreneurship courses based on projects are more helpful to students' entrepreneurship than traditional entrepreneurship courses. 


\section{NEXT STEPS}

This experimental class still stays in testing now, therefore it gets to only small ranges of students, giving only an influence moderately with its educational achievements. For the next step, we are considering bringing the mode of this experimental class into all the practical teaching in school to challenge the traditional teaching mode of entrepreneurial training. The following situation would happen probably that the increasing entrepreneurial projects, which is out of the increasing students, leads to a shortage of campus companies taking care of their entrepreneurial projects. Those are the problems that we are going to study and solve in next teaching phrase.

The core idea of this entrepreneurial education is the concept of Maker, which is also a developmental trend of entrepreneurial education. Currently the idea of Maker in our school is not well introduced to students and Maker is not very popularized. It calls for our educators to create an atmosphere for Maker, to create and environment for Maker, and to build more Maker Zone based on the previous entrepreneurial bases of college students, providing the Makers a venue to communicate and to do their business, so that the concept of Maker can be introduced in a better way in many universities.

\section{REFERENCES}

[1] Chu Yanfang, Yan Kong "the practice and exploration of the virtua simulation experimental teaching" Experimental Technology and Management. 2012(12):97-100

[2] Xu Siyan and Li Zhengfeng. A social network innovated by the public: Maker activity and Maker Zone. [J] Scientific Study. 2014(12):1789-1797

[3] Zhang Po. The Innovative Study of the Teaching Method in the Entrepreneurship Education in College.[J] Culture and Education Research: $131-132$

[4] LIU Xiaolu.XING Lining.YANG Zhenyu.SUN Kai. Practice of and thinking about teaching model of "Flipped class" [ J ]. Time Education, 2014 (5):63

[5] LIU Xeusong. Application study of teaching model of "Flipped class" [ J ]Education Research, 2014 (9):340

[6] Zengzhen. Characteristics, practice and problems of flipped teaching [ J ] China Educational Technology, 2012

[7] ZUO Wenjing The comparative Study on the Organization Model of University---wide Entrepreneurship Education between Chinese and American Universities. [ D ].Jilin. Northeast Normal University.2013:2328

[8] HUANG Zhaoxia .ZHAO Goujing.A comparison Between Entrepreneurship Education Curriculum of Universities

[9] ZHANG Po. Innovation study on teaching methods of entrepreneurship courses in universities[ J ]Wenjiao Ziliao.2015 (3) :131-132 